\title{
Women's Representation and Public Spending Helena Svaleryd
}




\title{
WOMEN'S REPRESENTATION AND PUBLIC SPENDING*
}

\author{
Helena Svaleryd ${ }^{+}$
}

September 2008

\begin{abstract}
This paper studies whether the degree of women's representation in Swedish local councils affects local public expenditure patterns. To empirically address the question, I first analyze the differences in preferences between men and women expressed by elected local council representatives using survey data. This enables me to make precise predictions about the effects of women's representation on spending. The subsequent panel study on the composition of public spending in Swedish municipalities supports the predictions derived from the survey.
\end{abstract}

JEL Classification: C23; C25; D78; H40; J16

Keywords: Political representation; Local public expenditure; Gender; Survey data; Panel data

\footnotetext{
* I am grateful to Henrik Jordahl, Torsten Persson, Jonas Vlachos, and seminar participants at the Economic Council in Stockholm, the Research Institute of Industrial Economics, Stockholm University and Uppsala University for useful suggestions and comments. I would also like to thank Per Pettersson-Lidbom for generously sharing his data set with me and Mark Blake for editorial support. This research is supported by grants from the Alhström and Terserus' Foundation and the Wallander and Hedelius Foundation. ${ }^{+}$The Research Institute of Industrial Economics, P.O. Box 55665, 10215 Stockholm, Sweden. E-mail: Helena.Svaleryd@ifn.se.
} 


\section{Introduction}

Do all groups have to be represented in elected assemblies for their interests to be taken into account? In the public debate, this is often claimed to be the case. Yet if political representation is necessary for one's interests being taken into account, it is implicitly assumed that the elected representative, at least to some degree, can pursue his or her own interests. Women are often referred to as an under-represented group in elected assemblies. ${ }^{1}$

This study investigates whether women's representation shapes actual policy choices in Swedish municipalities. Using survey data on the preferences of politicians in local governments, I first investigate if and how the preferences of men and women differ. This approach allows me to derive a set of precise hypotheses about the effects of gender on policy choices. This is of great merit. Instead of postulating à priori in what way men's and women's preferences differ, I derive clear predictions about the effect of women's representation on spending from the preference study. Then, I analyze the actual allocation of spending in all Swedish municipalities. The results indicate that the share of women on a local council indeed has a significant effect on spending decisions. As predicted by the preference study, a larger share of women in the local council increases spending on childcare and education relative to elderly care.

Theoretically, there is no clear answer as to whether the elected representative's gender is of importance for policy choices. Electoral incentives will to some degree encourage the elected representative to act according to the interest of the electorate, rather than his or her own interest. However, when electoral incentives are weak, it is theoretically plausible that politicians' preferences affect policy choices, and the bargaining strength of a group of politicians with similar preferences will be of importance for the allocation of resources (see e.g. Persson and Tabellini, 2000).

A basic prerequisite for representation of women to matter for policy is that men and women have different preferences regarding policy. There is ample evidence

\footnotetext{
${ }^{1}$ In the year 2005, e.g., only 16 percent of national parliament members worldwide were women (Ballington and Karam, 2005).
} 
suggesting that this is the case. Surveys of men and women's preferences using pools show that women are more concerned about social policy issues (see e.g. Funk and Garthmann, 2006, and, for evidence on Swedish data, Oskarson and Wängnerud, 1995). Among elected representatives there are also documented differences. In a study of Swedish MPs, Esaiasson and Holmberg (1993) find that female MPs were significantly more positive towards daycare centers and an ecological society than men. This paper also finds that there are important differences in the stated preferences of men and women.

Given that men and women's preferences differ, the question is if representation matters for policy. Greater representation of women in the electorate has been shown to be important. A strand of the literature on women's representation studies the impact of gender composition of the electorate on fiscal outcomes. By using the introduction of suffrage as an exogenous change to the composition of the constituency, the studies are able to show an effect of women on policy. A general finding is that women prefer higher social spending then men (see e.g. Lott and Kenny, 1999, Abrams and Settle, 1999 and Toke and Dallal, 2008).

The question studied in this paper is whether women's representation in the elected assembly matters for policy? Chattopadhyay and Duflo (2004) find women's representation to be important when studying local-level spending patterns in India. To establish a causal effect, they use the fact that one third of all leadership positions of Village Councils in West Bengal was randomly assigned to women. Besley and Case (2003) use panel data on U.S. states and find that women's representation increases spending on family assistance and strengthens child support provision. None of these papers include information about legislator preference and it is implied that changes in policy are attributed to changes in representation. Sorensen (1995) on the other hand uses the same methodology as this study. He first asks the politicians what their preferences are over different sectors and focuses on party affiliation and public sector employment, finding that although preferences are correlated with party affiliation and public sector employment, the representation of different groups has a limited impact on the spending pattern. This paper contributes to the literature on women's representation in elected assemblies by relating the stated preference of 
elected representatives, derived from a survey, to the revealed preference of spending decisions.

Most political economy models show that electoral incentives will reduce the impact of a politician's preferences on policy choices. Empirical literature has found that strong political competition seems to keep politicians in power from furthering their own interests, rather than the interests of the general public (see e.g. Kalt and Zupan, 1984, 1990, Besley et al, 2007, Besley and Case, 2003 and Svaleryd and Vlachos, 2007). This paper also provides evidence suggesting that political competition limits elected representatives from pursuing their own interest by showing that the effect of women's representation is smaller when political competition is strong.

A major advantage with studying Swedish municipalities is that since they work within the same legal and institutional system, many of the problems associated with cross-country studies are avoided. Still, local governments enjoy considerable autonomy from the national government, they set their own budget and exercise powers of taxation. That the autonomy from central government is not just formal has been shown in several empirical studies (e.g. Pettersson-Lidbom, 2008 and Svaleryd and Vlachos, 2007).

The paper is organized as follows. I first (see Section 2) examine the relationship between gender and preferences using survey data on the elected representatives in 28 Swedish municipalities. Then (Section 3) I study the effect of women's representation on actual local public expenditure in all Swedish municipalities, using the predictions derived in Section 2. Section 4 concludes.

\section{How do men's and women's preferences differ?}

To obtain predictions about the effect of women's representation on policy choices, men's and women's preferences need to differ in a systematic way. If there are no differences between men's and women's spending preferences, there is no reason to expect women's representation in the local council to be of importance for the municipality's spending pattern. 
Why then would women and men's preferences differ? Men and women do different things in the household which could affect their spending preferences of public resources. For example, women stay home with small children to a much larger extent than men. As mentioned in the Introduction, there is also ample evidence that men's and women's preferences differ over policy choices. In order to establish possible gender differences in preferences among politicians in Swedish municipalities, I employ a unique data set on the preferences expressed by elected representatives in Swedish municipalities in 1980 and $1993 .^{2}$

This study will focus on spending on elderly care, education and childcare. There are three main reasons for choosing these sectors. First of all they constitute the lion's share of municipal spending; second, the availability of the data is good; and third, municipalities are in principle the sole providers of these services.

\subsection{Data}

Elected representatives in 25 municipalities in 1980 and 28 municipalities in 1993 (about 10 percent of the local councils) were asked to participate in the survey. ${ }^{3}$ The municipalities were chosen by the original researcher to mirror the demographic, economic and political differences across municipalities in Sweden. Since the focus is on the local councils, only respondents who are members, or replacement deputies, in the local council are included, leaving me with around 1910 observations. The assumption will be that the preferences of these politicians are representative of the views of elected representatives in Swedish local councils. A closer examination of the average values of the variables used in the subsequent study of municipality spending patterns shows that there are negligible differences between those municipalities that were included in the study and those which were not. For example, the average share of women in the local council in the year 1980 was 27.79 percent, in the sample of municipalities included in the survey, and 27.97 percent in the sample

\footnotetext{
${ }^{2}$ The data set is handled and distributed by The Swedish Social Science Data Service at Gothenburg University. Gunnar Wallin, Department of Political Science, Stockholm University, originally collected the material in "Kommunalpolitikerundersökningen” 1979-1980 and Henry Bäck, Department of Social Science, Stockholm University, originally collected the material in "Kommunalpolitikerundersökningen" 1993. Neither Swedish Social Science Data Service, nor Gunnar Wallin and Henry Bäck bear any responsibility for the analysis or interpretation of the data as presented in this paper.

${ }^{3}$ The answering rate was about 75 percent.
} 
of municipalities not included. For the year 1993, the average was 33.74 and 33.24 percent respectively. Moreover, the results of the preferences study should be representative for the period since the following study of actual public expenditure will use data from 1976 to 1997.

The primary purpose of the original survey was to study elected representatives' views on their political role and working routines in the local councils. However, the data collected also includes background information on gender, age, party affiliation, participation in organizations and position on the elected council. Most importantly, for my purpose, it also includes the politicians' views on certain issues, and in what areas they thought the municipality should do more.

For each area, the respondent could choose from three different answers: "it is important to do more than the municipality is doing now"; "the municipality's efforts are sufficient"; or "the municipality's efforts can be reduced."4 The answers will be interpreted as the politicians' spending preferences for different sectors. Since municipalities in Sweden have power over the size of the budget, and no budget constraint was built into the questions, it is possible that some politicians answered that the municipality should do more (or less) in all areas. To remedy this problem, differences between answers are used and ordered into five categories. For example, the variable Childcare/Elderly care will take the value of 1 if the politician states that more should be done in elderly care and less in childcare. It will take the value of 2 both if he/she indicates that it is important to do more in elderly care while the work in childcare is sufficient, and if he/she answers that elderly care spending is sufficient, but that spending on childcare can be reduced. If the respondent states that he/she would like to do more in all areas, it will be interpreted as this person is not placing a higher priority on any one area in relation to another and the variable Childcare/Elderly care will take the value of 3, and so on. The coding is illustrated in Table 1.

(Table 1 here)

\footnotetext{
${ }^{4}$ See the Appendix for the exact question.
} 
As can be seen in the summary statistics shown in appendix Table A:1, the mean of the variable Elderly/Child is 2.728 . On average, elderly care is thus regarded as a more important sector than childcare. Whenever the mean is lower than 3 , the sector in the numerator is, on average, regarded as less important than the sector in the denominator. Judging by the means of the dependent variables, politicians would especially like to spend more on elderly care at the expense of childcare.

Should control variables be included when studying the correlation between gender and preferences over different sectors? Preferences are likely to be correlated with, and perhaps also determined by, personal characteristic such as age, education level, occupation, age of children and so forth. Men and women are likely to be different in these dimensions, which could be part of the reason why there are gender differences in preferences. In the subsequent study of the municipalities' spending patterns I will not have access to any data on the characteristics of the elected representative apart from gender and party affiliation. Thus, the gender variables will pick up all the differences between men and women due to differences in age, education and occupation, for example. Including controls other then party affiliation in the preference study would remove some of the variation between men and women that I will study in the subsequent study of the municipalities' spending patterns. As an example, suppose I include a control for age in the preference study thereby removing the effect of age on preferences. When studying the actual spending pattern I have no control for the age structure in the local council. Since the women in the council are on average younger, the representation variable will pick up both the effect of age and the effect of gender. Therefore, as long as the sample of politicians is representative for the population, it would be wrong to control for different personal characteristics that are correlated with gender.

Factors that only affect the survey population should be included. For example, one concern may be that preferences are affected by the municipal spending pattern. To control for this I include municipal and year fixed effects. 


\subsection{Results}

The effects of gender on the stated preferences are examined in an ordered logit model, controlling for party affiliation and municipality. Seeing that preferences for different sectors probably correlate with party affiliation, I include an indicator for when the individual belongs to a left-wing party. ${ }^{5}$ To gain efficiency, I pool the data for the two periods and include a dummy for 1993 to control for possible changes in preferences over time.

The results presented in Table 2 show that there is a clear effect of gender. Women, relative to men, regard childcare and education as more important sectors than elderly care. Furthermore, party affiliation is evidently correlated with preferences. In comparison to right-wing politicians, left-wing politicians rank childcare as the most important area. Notice also that over time, the preferences have shifted in favor of spending on elderly care relative to both childcare and education. ${ }^{6}$

\section{(Table 2 here)}

The sample is then divided along party lines to check whether the gender effect is different in left- and right-wing parties. In Tables 3 and 4, the results for left- and right-wing parties are presented, respectively. The effect of gender in left-wing parties is the same as for the total sample. Women, relative to men, prefer spending on child care and education relative to elderly care.

(Table 3 here)

In right-wing parties, however, women and men do not express different opinions concerning the relative importance of education contra elderly care. Rather, the results show that women prefer relatively more spending on childcare relative to all sectors.

\footnotetext{
${ }^{5}$ Parties categorized as 'left-wing' are the Left Party, the Social Democratic Party and the Environmental Party, and 'right-wing' are the Moderate Party, the Liberal Party, the Christian Democratic Party, the Centre Party and New Democracy. This categorization follows Petersson (1992) and Svaleryd and Vlachos (2007).

${ }^{6}$ Due to the construction of the independent variables, some variation in preferences may be lost. Specifically, some respondents may have different preferences over the two sectors, but state that they prefer more (or less) spending in both sectors. In that case, my variable will indicate that the respondent does not prefer any sector relative to the other, thereby suggesting that the data fails to pick-up all the variation in preferences. To find out more about this effect, I study the gender profile for those cases where the respondent prefers more (or less) spending in both sectors. Interestingly, women are over-
} 
The estimated coefficient on childcare relative to elderly care is not statistically significant on conventional levels, but the coefficient is in the same magnitude as in column 1. Although, the result should be interpreted with some care, due to the reduced sample, the results seem to indicate some differences between left-wing and right-wing parties.

(Table 4 here)

To sum up, the gender effect on the ranking of childcare versus elderly care appears to exist in both samples, although the effect differs somewhat between left-wing and right-wing politicians. In left-wing parties, gender seems to affect the importance of childcare and education relative to elderly care. In right-wing parties, the main difference is the preference for childcare relative to elderly care.

The study of politicians' preferences indicates certain differences between men and women. If politicians can pursue their own interests, the strength of women in the local council should be reflected in the municipalities' spending decisions. Notice that it would be incorrect to interpret the above result as suggesting that women regard childcare as the service with highest priority. What it says is that women regard childcare as more important than men do. As a matter of fact, both female and male politicians express preferences for more spending on elderly care at the expense of childcare. Thus, if elected politicians could affect policy in accordance with these preferences, it should be reflected in a trend: over time, more resources should be allocated to elderly care and education at the expense of childcare.

\section{Local public spending}

Section 2 established a relationship between spending preferences and gender. The next step is to find out if politicians' preferences are important for actual spending.

\subsection{Object of study - Swedish local governments}

The object of the empirical study is Swedish municipal spending, which constitutes more than 40 percent of Swedish public spending. Local governments in Sweden are

represented (under-represented) as respondents preferring more (less) spending in both sectors. Thus women, relative to men, favor increased spending in all three sectors. 
interesting units for study of collective choice, because they enjoy a significant independence from national government. In fact, they have the constitutional right of self-governance. Moreover, several empirical studies have shown that they indeed act independently from the national government (see e.g. Pettersson-Lidbom, 2008 and Svaleryd and Vlachos, 2007). Another attractive feature is that local governments, in contrast to country-level studies, operate in the same political framework, i.e. politicians are likely to have roughly the same effect in all municipalities.

Sweden has a parliamentary system and elections are held every third year ${ }^{7}$. The seats are divided according to the proportion of votes the parties get in the local election. All major decisions, including all budgetary decisions, are taken in the local council by simple majority rule. As is common in this type of system, there are a number of different parties represented in the local councils. Even if there are several different parties, they are often categorized as belonging to the left-or right-wing bloc due to the division on state level. ${ }^{8}$

This study covers 272 municipalities in Sweden and spans the period 1976-97. ${ }^{9}$ As mentioned earlier, the study focuses on spending on elderly care, education and childcare. Since the preference study only provides predictions about the effects on relative spending in different sectors, the ratios of spending will be used as dependent variables.

\subsection{Specification of empirical model and data}

Empirically, the purpose is to estimate the impact of female politicians on municipality spending patterns, while controlling for the municipality's demographic composition. This allows me to examine whether the politician's identity is of importance for policy choices. It can also be seen as a weak test of different political economy models: if politicians can commit to policy, then the bargaining strength of women in the local council should not affect policy decisions. With incomplete

\footnotetext{
${ }^{7}$ Every fourth year from the 1994 election.

${ }^{8}$ To see which parties are categorized as left- wing and right-wing see footnote 5.

${ }^{9}$ It includes all municipalities except those that were split during the period and three municipalities with responsibilities usually handled by the county council.
} 
commitment, however, variations in political representation should have an effect. It is not clear how the bargaining strength of women on the local councils should be measured. Here, I will use the share of women on the local council as a proxy for women's bargaining power over the budget process. Women in council is the number of women in the council divided by the total number of seats. This variable is constant over the election period. It should be a relevant proxy, since all budget decisions are taken by a simple majority vote in the local council. Other measures will also be used, including the share of women in the majority and dummy variables capturing nonlinear effects of representation.

During this period, there has been an immense increase in women's representation at all levels of Swedish government. In the election 1973, the average share of women in the local councils was only 17 percent, while in the last election studied it was up to 41 percent. There is also considerable variation across municipalities. For example, after the 1973 election, only 2 percent of the seats were occupied by women in Högsby and Tjörn, whereas Järfälla had 35 percent women. Also, after the 1994 election, women's representation on the council differs across municipalities, with 23 percent in Torsås and 53 percent in Bollnäs. Notice, however, that only in the last election did women constitute a majority in some elected assemblies and then only in three local councils. The share of women in the majority is somewhat higher: in the last election, 30 municipalities had a local council where there where more female than male representatives in the majority. Almost all of these majorities were leftwing. The ranking of municipalities according to women on the council has changed considerably over time. One example is Högsby, which had the lowest share of women on the council after the 1973 election and about the same share as Järfälla after the 1994 election (Järfälla was at the top of the table at the beginning of the period). The increase in the share of women on the council cannot therefore only be explained by a common trend.

An important question concerns problems of simultaneity: there may be an omitted variable, such as a community-specific preference for equality, which affects both spending decisions and women's representation. A preferred approach is to use some exogenous change in women's representation that is not correlated with the spending decision (see e.g. Chattopadhyay and Duflo, 2004). There are no such changes in 
Sweden that can be used for identification during this period. Note, however, that voters in Sweden could not directly show their preferences for a female or male politician by voting for that candidate. ${ }^{10}$ In the Swedish system, voters voted for a party list, not a candidate, and a voter had virtually no power to affect the names on the list as the order was entirely decided by the party. Moreover, parties at the local level had been under pressure from the national level to increase the share of women on the party list.

When trying to explain spending on different services, one must try to control for differences in the need for the service. Since services such as childcare, education and elderly care are directed towards certain age groups, it is natural to control for demographic structure. It is also possible that large age groups can exert political pressure on the local council to spend more on a service that benefits that particular group. In a typical median voter model, for example, the service from which the median voter benefits the most is of great importance for spending patterns (see e.g. Strömberg, 1999). I include the share of the population between the ages of 0 and 6 when explaining spending on childcare, the share of the population between 7 and 15 when explaining spending on basic education, and the share of the population older than 65 for spending on elderly care.

The percentage of left-wing votes will be included, since it is likely to affect the municipality's allocation of resources. The rationale is twofold. First, given that politicians can affect resource allocation, and that party affiliation has been shown to correlate with preferences, the bargaining strength of the party should have an effect. Second, the votes cast for left-wing parties may also reflect the preferences of the population for spending on different sectors. To further account for left- and rightwing parties prioritizing different sectors, I include dummies for when left-wing and right-wing parties are in the majority, i.e. have more then 50 percent of the votes.

As mentioned earlier, the demographic composition of the electorate has also been used to describe the identity of the median voter in empirical studies. Thus, age

\footnotetext{
${ }^{10}$ In the 1998 election, and outside the time period of this study, incremental change was introduced which for the first time enabled the electorate to vote for an individual candidate. For this reason, I will not include observations after 1998.
} 
variables pick up both cost differences and median voter effects. Female participation rates will also be included to pick up further cost differences, since the need for childcare should be greater when many women work outside the home. For the period 1985-1997, there is data available at the municipality level on the share of women in the workforce aged between 20 and 64 . When studying the longer time period, I use a county-level measure of the share of women in the workforce. ${ }^{11}$ Population is included in case it affects the relative price of the different services. To control for further possible median voter effects, a battery of other variables will be included, such as the share of women in the population, the share of the population with higher education and municipality mean income. Data on mean income and women in the population is available for the whole period, whereas data on higher education only exists from 1985. See Table A:2 for an overview of the variables, i.e. detailed description, data sources and summary statistics.

The general idea is that if policy decisions are entirely decided by the electorate, only variables describing the municipality's demographic composition should explain the spending pattern, and the composition of the local council should have no explanatory power. Inspecting the correlation matrix, Table A:3 in the Appendix reveals a positive correlation between women on the council and spending on childcare, relative to education and elderly care. There is a larger share of women in the council in leftwing municipalities, but no or little correlation between left-wing votes and the spending pattern. The age group variables are, as expected, correlated with spending on the associated sectors and the share of women working is positively correlated with spending on childcare.

Following the results from section 2, there are three equations to estimate, one for each spending ratio. The general specification is:

$$
y_{i t}=\beta z_{i t}+\gamma \boldsymbol{X}_{i t}+\lambda_{t}+v_{i}+\varepsilon_{i t},
$$

where $y_{i t}$ denotes a particular spending ratio in a municipality in a specific year, $z_{i t}$ is the representation of women in the local council and $\boldsymbol{X}_{i t}$ is the vector of control

\footnotetext{
${ }^{11}$ There were 25 counties in 1976-1992 and 21 counties in 1993-1997.
} 
variables mentioned above. For the rest, $\lambda_{t}$ is a time-specific effect, constant over municipalities, $v_{i}$ is a municipal-specific effect, constant over time, and $\varepsilon_{i t}$ is the usual residual.

During the period 1976-1997, Statistics Sweden has made some changes in the definitions of different categorizes of spending, with major revisions in 1978, 1988 and 1995. There have also been some changes in the responsibility of some areas between different levels of government during the period. Including year fixed effects is one way of controlling for common shocks for all municipalities. The quality of data with regards to comparability across municipalities should be very good, since Statistics Sweden spends considerable resources to ensure this is the case.

Naturally, the advantage of using panel data is that we may hold constant municipality-specific and time-specific influences on spending. Municipality fixed effects control for time invariant differences across municipalities that may influence policy choices. Year effects should pick up two types of effects. As mentioned above, they should take into account any impact on the policy outcome of common shocks to the municipalities. Second, if politicians can act according to their own preferences, the trend should comply with the politicians' average preferences. The analysis of preferences in Section 2 focused on the difference between men and women. For example, women, relative to men, were found to regard childcare as a more important area than elderly care. However, both men and women did in fact state elderly care to be the highest priority sector. Therefore, we expect that over time, municipalities will allocate a larger share of the budget to elderly care and that the year fixed effects will pick up this effect.

\subsection{Results}

\subsubsection{Female representation and spending pattern}

Table 5 presents the results from the basic panel regressions for the full set of municipalities. All specifications include the control variables described in the previous section and municipality and time fixed effects 
According to the preference study in Section 2, the effect of women's representation should affect spending on childcare and education relative to elderly care and have no impact on spending on childcare relative to education. The results presented in Table 4 suggest this is the case. Inspecting the first column, we see that the share of women on the local council has a positive effect on spending on childcare relative to spending on elderly care in the period 1976-1997. The next column shows there is no effect of women on the council on spending on childcare relative to education. Finally, the last column shows that spending on education relative spending on elderly care increases with the share of women on the council.

How large are the effects of women's representation on the spending ratios? To judge this, we can do the following thought experiment: suppose the share of women on the council increases with one standard deviation (about 9 percentage points), then spending on childcare relative to elderly care increases with about 10 percent for the municipality with the mean level of spending. ${ }^{12}$ The same calculation for the results in column three shows that spending on childcare relative to elderly care increases with almost 5 percent.

According to the study of politicians' preferences in Section 2, left-wing politicians considered childcare to be the most important sector. The results indeed show that the share of left-wing votes increases spending on childcare relative to the other sectors. There is, however, not any additional effect when the left-wing party is in majority. The demand for childcare is also strongly related to the female participation rate. An increase in the share of women in the population favors spending on elderly care in relation to other sectors. Population increases are also positively correlated with spending on elderly.

(Table 5 here)

Higher female participation rates should increase the demand for childcare, which they also do according to the results in Table 5. The measure available for the longer time period exists, however, only on county level. The specification presented in the first, third and fifth columns in Table 6 uses female participation rate on the 
municipality level rather than county level. In addition, one may worry that a more educated population priorities education and elected female politicians. To control for this I include the share of population with higher education. In column two, four and six, each municipality is allowed its own time trend to control for unobservable time varying effects.

The results in Table 6 show that the results are robust to the inclusion of the control variables and the municipality specific time trends. A larger share of highly educated representatives seems to increase spending on education and elderly care. The municipality level measure of female participation rates yields the same results as in the previous table. Including the time trends reduces the estimated coefficients, but there is still a statistically significant effect of female representation on the spending pattern. Note that municipality specific trends will, however, not only pick up effects of changes in unobservables, but also some of the effect of increased female representation on the spending pattern, since most municipalities increased their share of women in the council continuously over the period.

\section{(Table 6 here)}

\subsubsection{Other measures of women's representation}

How should we measure the bargaining strengths of elected representatives on local councils? In the previous specifications I have used the share of women on the council, reflecting that all elected representatives may have some bargaining power in the budget process, possibly because they can highlight these issues in council meetings and in the media, even though they are not part of the majority. If, on the other hand, the ruling parties alone determine the allocation of resources, only the bargaining strength of women in the majority is important for policy decisions. Table 7 presents the results from using the share of women in the majority as a proxy for female bargaining power in the council. ${ }^{13}$ There are possibly some measurement problems with this variable, since parties on the local level sometimes form coalitions with parties across the normal bloc boundaries and I only have access to the election

\footnotetext{
${ }^{12}$ Calculated as follows: $(0.089 \times 0.993) / 0.849$.
} 
results. Moreover, there are cases when not all left-wing (right-wing) parties are included in the left-wing (right-wing) majority. Notice also that this variable only is available for a shorter time period. The results presented in the first three columns show the same pattern as the previous tables: women's representation increases spending on childcare and education at the expense of elderly care.

Another concern may be that women's representation needs to reach a certain level to matter for the decision process (see e.g. Dahlerup, 1989). In this case, a linear approximation of the effect would not be appropriate. To better capture the effect I include three dummies representing different levels of women's representation. The results presented in the three last columns suggest that moving from less than 20 percent women in the local council to between 20-29 percent has no effect on the spending pattern. Interestingly, the results suggest that women's representation needs to reach at least 30 percent before representation in the local council translates into changes in policy. Spending on childcare relative to elderly care and education relative to elderly care is highest when the share of women in the council is more the 40 percent. There is also a small, but statistically significant, effect of women in the council on spending on childcare relative to education when moving to between 30 and 39 percent. However, increasing women's representation reduces the spending ratio even more, back to the level when the share of women on the council was below 30 percent. This last result is slightly difficult to interpret.

(Table 7 here)

\subsubsection{Dynamic effects}

The panel results presented so far have been static. There may, however, be high persistence in the spending pattern suggesting that a dynamic model is more appropriate. The within estimator will be biased and inconsistent in a dynamic set-up unless the panel consists of many time periods. When estimating dynamic models, one can use transformations that allow the use of lagged endogenous and predetermined variables as instruments for the transformed equations. Efficient GMM

\footnotetext{
${ }^{13}$ The number of women in the majority divided by the number of seats belonging to the majority. There is a left-wing majority if SAP + VP obtains more than 50 percent of the votes and a right-wing majority if $\mathrm{M}+\mathrm{Fp}+\mathrm{Kd}+\mathrm{C}$ obtain more than 50 percent of the votes.
} 
(generalized method-of-moments estimator) of this type are discussed in Arellano and Bond (1991) and Blundell and Bond (1998).

Table 8 displays the results from a dynamic model where the lagged dependent variable has been instrumented using the GMM method. The first three columns use the share of women in the council as proxy for women's representation, and the last three use the share of women in the majority. The Sargan test of over-identifying restrictions is used to control the model specification and the validity of the instruments. The consistency of the GMM estimator depends heavily upon the assumption of no second-order autocorrelation in the first-differences errors. Therefore, Table 8 also shows the test statistic of an AR(2) test.

The lag structure that seems to fit the data is to use two lags. As is evident from the results there is large persistence in the data. The proxies for women's representation show the same pattern as in previous tables. Using a dynamic panel, we are now able to study the long and short term effects of women' representation on spending patterns. Using the same thought experiment as in section 3.3.1, when calculating the effect estimated in the first column, we see that the short term effect on increased women's representation is almost 4 percent and the long term effect is 7 percent.

(Table 8 here)

\subsubsection{Differences between the left-wing and right-wing bloc}

The results from the preference study in Section 2 suggest some differences between left-wing and right-wing parties. The predictions from the preference study are that in left-wing parties, women prefer spending on child care and education relative to elderly care. In right-wing parties, the differences between men's and women's priorities centre around spending on child care relative to elderly care.

Interactions between the share of women in the council, and dummies for right-wing respective majority, are included to test the predictions. As can be seen in the first column of Table 9, there is a significant effect of women's representation on spending on childcare relative to elderly care in both samples. There are no significant effects of the share of women on the council on spending on childcare relative to education 
(column two), while there is again a positive effect of the share of women in the council on spending on education relative to elderly care, especially in left-wing majorities (column three). There is, however, still a smaller but positive effect of women's representation on spending on education relative to elderly care in rightwing parties, which is not in line with the predictions. Next we turn to another measure of women's representation: the share of women in the majority. Inspecting the first row in the second panel of Table 9 we see that the effect of women's representation in left-wing majorities is in line with the predictions. The effect of women's representation in right-wing majorities is not entirely according to the predicted effects. In particular, there is a positive effect on spending on education relative to elderly care, which is not predicted from the preferences study.

In sum, there is some support for the predictions derived in section 2, especially for left-wing parties. For right-wing parties, the results are not entirely in line with predictions.

(Table 9 here)

\subsubsection{Political competition and the impact of women's representation}

Models of electoral competition show that political competition limits the possibility for elected representatives to further their own interest. In most theoretical models, this is modeled as rents that accrue to the politician or the political party in power (see Persson and Tabellini, 2000 for an overview of political agency models and Svaleryd and Vlachos, 2007 for an example in the context of a probabilistic voting model). It is not always clear what these rents are, but empirical studies have studied money transfers and slack and inefficiencies in policy making (Besley et al, 2007, Besley and Case, 2003 and Svaleryd and Vlachos, 2007). Another way to further one's own interest is to make policy choices according to one's own preferences. An early contribution to this literature is Kalt and Zupan (1984) who discuss the nature of these rents and write quote [ .., shirking by legislators may focus on nonpecuniary perquisites of holding office.. The perquisites of political office range from "fact finding" junkets and ....prestige, and the ability to use the power of government to impose one's own pet theories of the "good" society.] The prediction would in the context of this study then be that politicians' preferences for different sectors should 
have a greater influence on policy in municipalities characterized with weak electoral incentives.

This hypothesis is tested on the data. A commonly used measure of electoral incentives or political competition is the absolute difference between the vote share of the left- and right-wing blocs (see e.g. Besley and Case, 2003 and Svaleryd and Vlachos, 2007). Political competition is then weaker the larger the differences between the vote shares of the two blocs. Here, Political competition is defined as 1 minus the absolute difference between blocs. To study if women's representation in the local council has a greater effect on the spending pattern when political competition is weak, the measure of political competition is interacted with the measure of women's representation.

The results presented in Table 10 lend some support to the hypothesis that political competition reduces the independence of the legislator and thus the impact of personal preferences on policy. The results using the share of women in the majority, presented in the last three columns, are exactly in line with the predictions. The share of women in the majority increases spending on childcare relative to elderly care, but less so when political competition is strong (column four). There is also a positive effect of political competition on childcare spending relative to spending on elderly care. One interpretation is that on average the council does not adequately represent the electorate, in particular, by not furthering the interests of women and by putting too low a priority on childcare relative to elderly care. This same pattern is evident for spending on education relative to elderly care (see results presented in the last column). According to the results in the fifth column, there are no effects on spending on childcare relative to education by changes in the share of women in the majority.

The share of women in the council, however, seems to have a positive effect on spending on childcare relative to elderly care when political competition is strong. The results in column one and three display the same pattern as for the other measure of women's representation, the share of women in the majority, although the results are not statistically significant.

(Table 10 here) 


\section{Conclusion}

Male and female local politicians prioritize different sectors. These differences shape local spending patterns, since women's representation on municipal councils is shown to affect how the resources are divided across sectors. This study provides further evidence for the idea that the identity of the elected representative is important for policy decisions, thereby supporting the results found in Chattopadhyay and Duflo (2004) and Besley and Case (2003).

This study is not able to fully control for endogeneity of women's representation, i.e. that something else is determining both the share of women in the council and the spending pattern. However, several results point in the same direction. In a survey, female and male politicians show different priorities across sectors. These differences appear in the data when studying the spending pattern in a panel. The results are robust to a number of robustness checks. Moreover, women's representation has a larger effect when political competition is weak, suggesting that politicians' own preferences have a greater impact when (re)electoral incentives are weak.

One potential policy conclusion would be that women need to be represented on elected assemblies for their opinions to be taken into account. This would, however, assume that female politicians and female voters have the same policy preferences. Chattopadhyay and Duflo (2004) show some evidence of this being the case in their study of Indian villages, as women leaders seem to address, to a greater extent, the concerns of women in the village. However, there is also some evidence that the preferences of voters and politicians may not coincide. In a study of Swedish municipalities, Ågren et al (2007) find that female politicians have significantly different spending preferences than female voters.

The focus here has been on gender as a determinant of spending. Clearly, other dimensions of local council composition could also affect policy. For example, a municipality with older politicians is likely to spend more on the elderly. Other characteristics, such as ethnic group and occupation, may also be correlated with 
preferences and therefore have an impact on policy decisions. There is clearly room for further studies along similar lines. 


\section{Appendix}

Question from a survey of local government politicians. (Kommunalpolitikerundersökningen, 1979-1980 SSD0101 and 1993 SSD 0459).

For each of the three sectors, childcare, education and elderly care, the respondents answered the following question:

Do you think it is important that your municipality does more than at present, its present effort is essentially sufficient, its present effort can be reduced, or you do not have an opinion?
A. Important to do more
B. Sufficient as it is
C. Can be reduced
D. Do not know / no opinion.

(Own translation) 
Table A:1 Descriptive statistics for the study in Section 2.

\begin{tabular}{l|ccc}
\hline Variable & Mean & Standard deviation & Nobs \\
\hline & & & \\
Female & 0.300 & 0.458 & 1948 \\
Childcare/ Elderly care & 2.728 & 0.627 & 1910 \\
Childcare/ Education & 2.839 & 0.666 & 1910 \\
Education/ Elderly care & 2.884 & 0.630 & 1910 \\
\hline
\end{tabular}

Data source: Kommunalpolitikerundersökningen 1979-80 SSD 0101 and 1993 SSD 0459 
Table A:2. Descriptive statistics and data sources for data used in Sections 3.

\begin{tabular}{|c|c|c|c|c|}
\hline Variable & Source & Mean & Std.d & $N o b s$ \\
\hline $\begin{array}{l}\text { Childcare / elderly care: Spending on childcare divided by spending on } \\
\text { elderly care. }\end{array}$ & $\mathrm{SS}^{1}$ & 0.849 & 0.815 & 5436 \\
\hline $\begin{array}{l}\text { Childcare / education: spending on childcare divided by spending on } \\
\text { education. }\end{array}$ & $\mathrm{SS}^{1}$ & 0.635 & 0.278 & 5603 \\
\hline $\begin{array}{l}\text { Education / elderly care: Spending on education divided by spending on } \\
\text { elderly care. }\end{array}$ & $\mathrm{SS}^{1}$ & 1.297 & 0.8245 & 5425 \\
\hline $\begin{array}{l}\text { Women on the local council: The number of women on the local council } \\
\text { divided by the number of seats in the local council. }\end{array}$ & $\begin{array}{c}\text { SS \& } \\
\text { SALAR }^{2}\end{array}$ & 0.302 & 0.089 & 5880 \\
\hline $\begin{array}{l}\text { Women in the majority: The number of women in the majority divided } \\
\text { by the number of seats belonging to the majority. There is a left-wing } \\
\text { majority if SAP }+\mathrm{VP} \text { obtains more than } 50 \text { percent of the votes and a } \\
\text { right-wing majority if } \mathrm{M}+\mathrm{Fp}+\mathrm{Kd}+\mathrm{C} \text { obtain more than } 50 \text { percent of the } \\
\text { votes. }\end{array}$ & SS & 0.334 & 0.100 & 3582 \\
\hline Left-wing votes: The share of votes cast on SAP, VP and Mp. & SS & 0.497 & 0.118 & 5880 \\
\hline $\begin{array}{l}\text { Left-wing majority: A dummy that takes the value } 1 \text { when the left-wing } \\
\text { parties have more then } 50 \text { percent of the votes }\end{array}$ & SS & 0.484 & 0.500 & 5880 \\
\hline $\begin{array}{l}\text { Right-wing majority: A dummy that takes the value } 1 \text { when the right- } \\
\text { wing parties have more then } 50 \text { percent of the votes }\end{array}$ & SS & 0.425 & 0.494 & 5880 \\
\hline $\begin{array}{l}\text { Political competition: } 1 \text { - absolute differences between left-wing and } \\
\text { right-wing votes. }\end{array}$ & SS & 0.812 & 0.138 & 5880 \\
\hline Ages 0-6: The share of the population between 0 and 6 . & SS & 0.089 & 0.012 & 5880 \\
\hline Ages 7-15: The share of the population between 7 and 15 . & SS & 0.121 & 0.017 & 5880 \\
\hline Ages 65 and older: The share of the population older than 65 . & SS & 0.180 & 0.042 & 5880 \\
\hline $\begin{array}{l}\text { Mean income: Taxable personal income per person. Deflated using KPI } \\
\text { to } 1997 \text { year prices. }\end{array}$ & $\mathrm{SS}^{3}$ & 84876 & 14289 & 5880 \\
\hline Women in the population: The share of women in the population. & SS & 0.499 & 0.013 & 5880 \\
\hline Population: size of population. & SS & 27269 & 45942 & 5880 \\
\hline $\begin{array}{l}\text { Women's participation rate in the sample 1974-1997: The share of } \\
\text { women who are part of the workforce and not unemployed at the county } \\
\text { level. }\end{array}$ & SS & 0.733 & 0.050 & 5880 \\
\hline $\begin{array}{l}\text { Women's participation rate 1985-1997: The share of working women } \\
\text { aged 20-64 in November. }\end{array}$ & SS & 0.768 & 0.057 & 3212 \\
\hline $\begin{array}{l}\text { High education: Share of the population with three years or more of } \\
\text { higher education. }\end{array}$ & SS & 0.099 & 0.045 & 3482 \\
\hline
\end{tabular}

SS (Statistics Sweden) www.scb.se, SALAR (The Swedish Association of Local Authorities and Regions).

${ }^{1}$ Data from "räkenskapssammandraget" collected by Statistics Sweden and calculated by Per

Pettersson-Lidbom 1974-1989. 1988-1997 data published in "How much do local public services cost in Sweden?"

${ }^{2}$ Published in "Kommunlat förtroendevalda. Parti och kön nämndorganisation lokala organ" 1977 and 1980

${ }^{3}$ Published in "Statistical yearbook of administrative districts of Sweden." 
Appendix A:3 Correlation matrix for variables used in Sections 3.

\begin{tabular}{|c|c|c|c|c|c|c|c|c|c|c|c|c|c|c|c|}
\hline & $\begin{array}{l}\text { Child/ } \\
\text { elderly }\end{array}$ & $\begin{array}{l}\text { Child/ } \\
\text { edu }\end{array}$ & $\begin{array}{c}\text { Edu/ } \\
\text { Elderly }\end{array}$ & $\begin{array}{l}\text { Women } \\
\text { council }\end{array}$ & $\begin{array}{c}\text { Women } \\
\text { maj }\end{array}$ & Left-wing & Age06 & Age 715 & Age65 & $\begin{array}{c}\text { Women } \\
\text { working } \\
\text { (county) }\end{array}$ & $\begin{array}{c}\text { Women } \\
\text { working } \\
\text { (mun) }\end{array}$ & $\begin{array}{c}\text { Mean } \\
\text { income }\end{array}$ & $\begin{array}{c}\text { Women } \\
\text { pop }\end{array}$ & Pop & $\begin{array}{c}\text { High } \\
e d u\end{array}$ \\
\hline Child/elderly & 1.000 & & & & & & & & & & & & & & \\
\hline Child/edu & 0.464 & 1.000 & & & & & & & & & & & & & \\
\hline Edu/elderly & 0.900 & 0.110 & 1.000 & & & & & & & & & & & & \\
\hline $\begin{array}{l}\text { Women in } \\
\text { council }\end{array}$ & 0.160 & 0.348 & 0.012 & 1.000 & & & & & & & & & & & \\
\hline $\begin{array}{l}\text { Women in } \\
\text { majority }\end{array}$ & 0.078 & 0.294 & -0.066 & 0.867 & 1.000 & & & & & & & & & & \\
\hline Left-wing & -0.097 & 0.027 & -0.133 & 0.240 & 0.358 & 1.000 & & & & & & & & & \\
\hline Age06 & 0.156 & 0.104 & 0.142 & 0.238 & 0.166 & -0.300 & 1.000 & & & & & & & & \\
\hline Age 715 & 0.418 & -0.082 & 0.547 & -0.154 & -0.212 & -0.329 & 0.368 & 1.000 & & & & & & & \\
\hline Age65 & -0.682 & -0.430 & -0.621 & -0.241 & -0.140 & 0.109 & -0.557 & -0.572 & 1.000 & & & & & & \\
\hline Women work (county) & 0.529 & 0.115 & 0.597 & -0.251 & -0.311 & -0.177 & -0.213 & 0.249 & -0.176 & 1.000 & & & & & \\
\hline Women work(mun) & 0.560 & 0.207 & 0.596 & -0.215 & 0.438 & -0.219 & -0.096 & 0.351 & -0.339 & 0.839 & 1.000 & & & & \\
\hline Mean income & 0.411 & 0.522 & 0.252 & 0.538 & 0.109 & -0.012 & 0.290 & -0.109 & -0.509 & 0.045 & 0.139 & 1.000 & & & \\
\hline Women pop & 0.269 & 0.474 & 0.145 & 0.191 & 0.228 & -0.230 & 0.036 & -0.017 & -0.237 & 0.226 & 0.312 & 0.466 & 1.000 & & \\
\hline Pop & 0.154 & 0.473 & 0.008 & 0.234 & -0.296 & -0.000 & -0.030 & -0.212 & -0.146 & 0.093 & 0.078 & 0.328 & 0.435 & 1.000 & \\
\hline High edu & 0.347 & 0.540 & 0.174 & 0.482 & 0.375 & -0.214 & 0.347 & -0.006 & -0.505 & -0.042 & 0.077 & 0.812 & 0.587 & 0.423 & 1.000 \\
\hline
\end{tabular}




\section{References}

Abrams, B. and Settle, R., 1999. “Women's suffrage and the growth of the welfare state." Public Choice 100: 289-300

Ågren, H., Mörk, E. and Dahlberg, M., 2007. ” Do politicians’ preferences correspond to those of the voters? An investigation of political representation." Public Choice 130:137-162

Arellano, M. and Bond, S., 1991. "Some tests of specification for panel data: Monte Carlo evidence and an application to employment equations." The Review of Economic Studies 58: 277-97.

Ballington, J. and Karam, A., 2005. Women in parliament: Beyond numbers. A revised edition. The international IDEA handbook series, Stockholm.

Besley, T. and Case, A. 2003., "Political institutions and policy choices: Empirical evidence from the United States." Journal of Economic Literature 41:7-73.

Besley, T., Persson, T and Sturm, D., 2007 "Political Competition and Economic Performance: Theory and Evidence from the United States", NBER Working Paper 11484.

Blundell, R. and Bond S., 1998. " Initial conditions and moment restrictions in dynamic panel data models" Journal of Econometrics 87: 115-43.

Chattopadhyay, R. and Duflo, E., 2004. "Women as policy makers: Evidence from a randomized policy experiment in India." Econometrica 72: 1409-43.

Dahlerup, D., 1989. 'From a Small to a Large Minority: Theory of Critical Mass.' Scandinavian Political Studies. Vol. 11, no. 4, pp. 275-98

Funk, P. and Garthmann, C., 2007. "What Women Want: Women Suffrage, Gender Gaps in Voter Preferences and Government Expenditures", SSRN working paper

Kenny, L. and Lott, J. 1999, "Did womens's suffrage change the size and scope of government?” Journal of Political Economy 107:1163-1198.

Matland, R., 1998. "Women's representation in national legislatures: Developed and developing countries.” Legislative Studies Quarterly 23:109-125.

Oskarson, M. and Wängnerud, L., 1995. Kvinnor som Väljare och Valda. Om Betydelsen av Kön i Svensk Politik. Studentlitteratur.

Persson, T. and Tabellini, G., 2000. Political Economics - Explaining Economic Policy, MIT Press: Cambridge

Petersson, O., 1992. Kommunalpolitik. Publica, Stockholm. 
Pettersson-Lidbom, P., 2008. "Do parties matter for economic outcomes? A regression discontinuity approach" Journal of the European Economic Association 6: 1037-1056 .

Roodman, D., 2006. "How to Do xtabond2: An Introduction to "Difference" and "System" GMM in Stata" Working Paper 103. Center for Global Development, Washington.

Sorensen, R., 1995. “The demand for local government goods.” European Journal of Political Research 27: 119-141.

Strömberg, D.,1999. "Demography, voting and public expenditures: Theory and evidence from Swedish municipalities.” Institute for International Economics, Stockholm University.

Svaleryd, H. and Vlachos, J., 2007. "Political rents in a mature democracy", Working paper 698, The Research Institute of Industrial Economics

Swedish Association of Local Authorities 1988-1997. Vad Kostar Verksamheten i din Kommun? (English title: How much do local public services cost in Sweden?)

Statistics Sweden SCB 1988-1999. Årsbok för Sveriges Kommuner. (English title: Statistical yearbook of administrative districts of Sweden)

Statistics Sweden SCB 1999. "Nominerade och valda kandidater vid de allmänna valen 1998." Statistiska Meddelanden.

Toke A. and Dallal B., (2008) "Female voting power: the contribution of women's suffrage to the growth of social spending in Western Europe (1869-1960)." Public Choice 134: 391-417 
Table 1. Illustration of the coding of survey responses.

\begin{tabular}{ccccc} 
& & \multicolumn{3}{c}{ Childcare } \\
& & Less & Same & More \\
\cline { 2 - 5 } Elderly care & 3 & 4 & 5 \\
& Same & 2 & 3 & 4 \\
& More & 1 & 2 & 3
\end{tabular}


Table 2. Politicians' preferences over sectors.

\begin{tabular}{l|ccc}
\hline & Childcare/ elderly care & Childcare/ education & Education/ elderly care \\
\hline \multirow{2}{*}{ Woman } & & & \\
& $0.338^{* * *}$ & 0.028 & $0.274^{* *}$ \\
Left-wing & $(2.68)$ & $(0.30)$ & $(2.22)$ \\
& $1.062^{* * *}$ & $1.066^{* * *}$ & -0.046 \\
Year 1993 & $(7.76)$ & $(8.89)$ & $(0.34)$ \\
& $-2.430^{* * *}$ & $-1.072^{* * *}$ & $-1.804^{* * *}$ \\
Municipality - year & $(24.85)$ & $(14.28)$ & $(28.19)$ \\
Effects & & & \\
& Yes & Yes & \\
Pseudo $\mathrm{R}^{2}$ & & & \\
Obs & 0.078 & 0.100 & 0.061 \\
\hline Estimates & 1910 & 1910 \\
\hline
\end{tabular}

Estimated using ordered logit and standard errors are clustered on municipality. T-

statistics in parentheses. $* * *$ indicate statistical significance at the $1 \%, * * 5 \%$ and $* 10 \%$ level. 
Table 3. Left-wing politicians' preferences over sectors

\begin{tabular}{l|ccc}
\hline & Childcare/ elderly care & Childcare/ education & Education/ elderly care \\
\hline & & & \\
Women & $0.520^{* * *}$ & -0.151 & $0.549^{* * *}$ \\
Year 1993 & $(3.53)$ & $(1.11)$ & $(3.58)$ \\
& $-2.014 * * *$ & $-1.542^{* * *}$ & $-0.175^{* * *}$ \\
Municipality - year & $(13.02)$ & $(15.29)$ & $(2.65)$ \\
Effects & Yes & Yes & Yes \\
Pseudo R & & & \\
Obs & 0.097 & 0.143 & 0.101 \\
\hline
\end{tabular}

Only individuals from the Social Democrats, the Environmental Party and the Left Party are included. Estimated using ordered logit and standard errors are clustered on

municipality. T-statistics in parentheses. $* * *$ indicate statistical significance at the $1 \%, * *$ $5 \%$ and $* 10 \%$ level. 
Table 4. Right-wing politicians' preferences over sectors

\begin{tabular}{l|ccc}
\hline & Childcare/ elderly care & Childcare/ education & Education/ elderly care \\
\hline Women & $0.297^{*}$ & 0.222 & 0.060 \\
& $(1.75)$ & $(1.44)$ & $(0.37)$ \\
Year 1993 & $-0.780^{* * *}$ & $-1.454^{* * *}$ & $0.733^{* * *}$ \\
& $(13.38)$ & $(16.55)$ & $(13.95)$ \\
Municipality - year & Yes & Yes & Yes \\
Effects & & & \\
Pseudo R & & & \\
Obs & 0.062 & 0.072 & 0.084 \\
\hline
\end{tabular}

Only individuals from the Moderate Party, the Liberal Party, the Center Party and the Christian Democratic Party are included. Estimated using ordered logit and standard errors are clustered on municipality. T-statistics in parentheses. $* * *$ indicate statistical significance at the $1 \%, * * 5 \%$ and $* 10 \%$ level 
Table 5. Women's representation and spending

\begin{tabular}{|c|c|c|c|}
\hline & Childcarelelderly & Childcare/education & Education/elderly \\
\hline Period & 1976-1997 & 1976-1997 & 1976-1997 \\
\hline Women in council & $\begin{array}{c}0.993 \\
(3.39)^{* * *}\end{array}$ & $\begin{array}{l}0.104 \\
(1.36)\end{array}$ & $\begin{array}{c}0.715 \\
(3.19)^{* * *}\end{array}$ \\
\hline Left-wing & $\begin{array}{c}0.955 \\
(2.21)^{* *}\end{array}$ & $\begin{array}{c}0.404 \\
(3.24)^{* * *}\end{array}$ & $\begin{array}{l}0.473 \\
(1.37)\end{array}$ \\
\hline Left-wing majority & $\begin{array}{l}0.002 \\
(0.04)\end{array}$ & $\begin{array}{l}0.004 \\
(0.22)\end{array}$ & $\begin{array}{l}-0.029 \\
(0.77)\end{array}$ \\
\hline Right-wing majority & $\begin{array}{l}-0.060 \\
(1.22)\end{array}$ & $\begin{array}{l}-0.014 \\
(0.85)\end{array}$ & $\begin{array}{l}-0.031 \\
(0.83)\end{array}$ \\
\hline Share age $0-6$ & $\begin{array}{c}-7.638 \\
(2.28)^{* *}\end{array}$ & $\begin{array}{c}1.513 \\
(2.77)^{* * *}\end{array}$ & \\
\hline Share age $7-15$ & & $\begin{array}{c}-2.462 \\
(4.19) * * *\end{array}$ & $\begin{array}{c}17.240 \\
(7.91)^{* * *}\end{array}$ \\
\hline Share age $65+$ & $\begin{array}{c}-15.028 \\
(5.14) * * *\end{array}$ & & $\begin{array}{c}-11.195 \\
(6.07) * * *\end{array}$ \\
\hline Women working & $\begin{array}{c}3.810 \\
(4.15)^{* * *}\end{array}$ & $\begin{array}{c}1.094 \\
(4.09) * * *\end{array}$ & $\begin{array}{c}0.987 \\
(1.67)^{*}\end{array}$ \\
\hline Mean income & $\begin{array}{c}-0.078 \\
(0.23)\end{array}$ & $\begin{array}{c}0.292 \\
(2.42)^{* *}\end{array}$ & $\begin{array}{l}-0.297 \\
(1.07)\end{array}$ \\
\hline Women in pop & $\begin{array}{c}-1.770 \\
(1.43)\end{array}$ & $\begin{array}{l}0.137 \\
(0.19)\end{array}$ & $\begin{array}{l}-3.269 \\
(1.95)^{*}\end{array}$ \\
\hline Population & $\begin{array}{c}-2.068 \\
(5.03) * * *\end{array}$ & $\begin{array}{c}-0.137 \\
(1.80)^{*}\end{array}$ & $\begin{array}{c}-2.118 \\
(6.25)^{* * *}\end{array}$ \\
\hline $\begin{array}{l}\text { Year FE } \\
\text { Mun. FE }\end{array}$ & $\begin{array}{l}\text { yes } \\
\text { ves }\end{array}$ & $\begin{array}{l}\text { yes } \\
\text { ves }\end{array}$ & yes \\
\hline $\begin{array}{l}\text { Obs } \\
\mathrm{R}^{2}\end{array}$ & $\begin{array}{c}5436 \\
0.84\end{array}$ & $\begin{array}{c}5603 \\
0.84\end{array}$ & $\begin{array}{c}5425 \\
0.88\end{array}$ \\
\hline
\end{tabular}

Standard errors are clustered on municipality level and t-statistics are presented in parentheses.

$* *$ indicate statistical significance at the $1 \%$, ** $5 \%$ and $* 10 \%$ level. All variables not

expressed as shares, i.e Population and Average income, are in log-form. 
Table 6. Alternative specifications.

\begin{tabular}{|c|c|c|c|c|c|c|}
\hline & $\begin{array}{c}\text { Childcarel } \\
\text { elderly }\end{array}$ & $\begin{array}{c}\text { Childcare } \\
\text { lelderly }\end{array}$ & $\begin{array}{l}\text { Childcare } \\
\text { leducation }\end{array}$ & $\begin{array}{l}\text { Childcarel } \\
\text { education }\end{array}$ & $\begin{array}{c}\text { Education/ } \\
\text { elderly }\end{array}$ & $\begin{array}{c}\text { Education/ } \\
\text { elderly }\end{array}$ \\
\hline Period & $1985-1997$ & 1976-1997 & $1985-1997$ & 1976-1997 & 1985-1997 & 1976-1997 \\
\hline Women in council & $\begin{array}{c}1.012 \\
(3.67) * * *\end{array}$ & $\begin{array}{c}0.595 \\
(2.55)^{* * *}\end{array}$ & $\begin{array}{l}0.070 \\
(0.94)\end{array}$ & $\begin{array}{l}0.135 \\
(1.58)\end{array}$ & $\begin{array}{c}0.824 \\
(3.26)^{* * *}\end{array}$ & $\begin{array}{c}0.349 \\
(1.97)^{* *}\end{array}$ \\
\hline Left-wing & $\begin{array}{l}0.638 \\
(1.20)\end{array}$ & $\begin{array}{l}0.356 \\
(0.83)\end{array}$ & $\begin{array}{c}0.314 \\
(2.27)^{* *}\end{array}$ & $\begin{array}{c}0.322 \\
(2.28)^{* *}\end{array}$ & $\begin{array}{l}0.239 \\
(0.57)\end{array}$ & $\begin{array}{l}-0.226 \\
(0.74)\end{array}$ \\
\hline Left-wing maj. & $\begin{array}{l}-0.031 \\
(0.67)\end{array}$ & $\begin{array}{l}0.049 \\
(1.22)\end{array}$ & $\begin{array}{l}-0.006 \\
(0.42)\end{array}$ & $\begin{array}{l}0.009 \\
(0.52)\end{array}$ & $\begin{array}{l}-0.054 \\
(1.29)\end{array}$ & $\begin{array}{l}0.029 \\
(0.84)\end{array}$ \\
\hline Right-wing maj. & $\begin{array}{c}-0.102 \\
(2.39)^{* *}\end{array}$ & $\begin{array}{l}-0.050 \\
(1.16)\end{array}$ & $\begin{array}{l}-0.020 \\
(1.69)^{*}\end{array}$ & $\begin{array}{l}-0.017 \\
(0.84)\end{array}$ & $\begin{array}{l}-0.074 \\
(1.96)^{*}\end{array}$ & $\begin{array}{l}-0.015 \\
(0.51)\end{array}$ \\
\hline Share age $0-6$ & $\begin{array}{l}-10.240 \\
(2.46) * *\end{array}$ & $\begin{array}{c}-20.890 \\
(5.61) * * *\end{array}$ & $\begin{array}{l}1.780 \\
(1.17)\end{array}$ & $\begin{array}{l}0.871 \\
(1.00)\end{array}$ & & \\
\hline Share age $7-15$ & & & $\begin{array}{c}-3.616 \\
(2.27)^{* *}\end{array}$ & $\begin{array}{c}-2.431 \\
(3.19) * * *\end{array}$ & $\begin{array}{c}18.119 \\
(4.38)^{* * * *}\end{array}$ & $\begin{array}{c}4.374 \\
(2.46)^{* *}\end{array}$ \\
\hline Share age $65+$ & $\begin{array}{c}-26.506 \\
(5.82)^{* * *}\end{array}$ & $\begin{array}{c}-10.769 \\
(3.22) * * *\end{array}$ & & & $\begin{array}{c}-20.937 \\
(6.42)^{* * *}\end{array}$ & $\begin{array}{c}-9.516 \\
(3.81)^{* * *}\end{array}$ \\
\hline Women working & $\begin{array}{c}2.096 \\
(3.01)^{* * * *}\end{array}$ & $\begin{array}{c}0.920 \\
(1.73)^{*}\end{array}$ & $\begin{array}{c}1.370 \\
(6.24)^{* * *}\end{array}$ & $\begin{array}{c}0.513 \\
(2.35)^{* *}\end{array}$ & $\begin{array}{l}0.020 \\
(0.03)\end{array}$ & $\begin{array}{l}0.023 \\
(0.06)\end{array}$ \\
\hline Mean income & $\begin{array}{l}0.236 \\
(0.39)\end{array}$ & $\begin{array}{l}0.244 \\
(0.64)\end{array}$ & $\begin{array}{c}0.619 \\
(3.04)^{* * *}\end{array}$ & $\begin{array}{c}-0.183 \\
(1.39)\end{array}$ & $\begin{array}{l}0.106 \\
(0.20)\end{array}$ & $\begin{array}{c}0.459 \\
(1.86)^{*}\end{array}$ \\
\hline Women in pop & $\begin{array}{l}-2.931 \\
(1.03)\end{array}$ & $\begin{array}{c}6.563 \\
(2.88)^{* * *}\end{array}$ & $\begin{array}{c}4.693 \\
(2.22)^{* *}\end{array}$ & $\begin{array}{l}1.824 \\
(1.59)\end{array}$ & $\begin{array}{c}-14.294 \\
(3.94)^{* * *}\end{array}$ & $\begin{array}{l}-1.367 \\
(0.72)\end{array}$ \\
\hline Population & $\begin{array}{c}-3.758 \\
(3.82)^{* * * *}\end{array}$ & $\begin{array}{c}3.059 \\
(2.58)^{* *}\end{array}$ & $\begin{array}{l}-0.077 \\
(0.40)\end{array}$ & $\begin{array}{l}0.487 \\
(1.25)\end{array}$ & $\begin{array}{c}-3.740 \\
(4.29)^{* * *}\end{array}$ & $\begin{array}{l}0.417 \\
(0.51)\end{array}$ \\
\hline Higher education & $\begin{array}{c}-5.330 \\
(2.22)^{* *}\end{array}$ & & $\begin{array}{c}-3.198 \\
(2.05)^{* *}\end{array}$ & & $\begin{array}{l}2.742 \\
(1.28)\end{array}$ & \\
\hline Year FE & yes & Yes & yes & yes & yes & yes \\
\hline Mun. FE & yes & Yes & yes & yes & yes & yes \\
\hline Mun.trends & no & Yes & no & yes & no & yes \\
\hline $\begin{array}{l}\text { Obs } \\
\mathrm{R}^{2}\end{array}$ & $\begin{array}{c}3158 \\
0.86 \\
\end{array}$ & $\begin{array}{c}5436 \\
0.91\end{array}$ & $\begin{array}{c}3069 \\
0.83\end{array}$ & $\begin{array}{c}5603 \\
0.88\end{array}$ & $\begin{array}{c}3023 \\
0.87\end{array}$ & $\begin{array}{c}5425 \\
0.92\end{array}$ \\
\hline
\end{tabular}

Standard errors are clustered on municipality level and t-statistics are presented in parentheses. *** indicate statistical significance at the $1 \%, * * 5 \%$ and $* 10 \%$ level. In columns 1, 3 and 5, the measure for the share of working women in the population is a municipality-level measure of women in the workforce and in columns 2, 4 and 6, the measure of women working is on the county level. All variables not expressed as shares, i.e Population and Average income, are in log-form. 
Table 7. Other proxies for women's representation.

\begin{tabular}{|c|c|c|c|c|c|c|}
\hline & $\begin{array}{l}\text { Childcarel } \\
\text { elderly }\end{array}$ & $\begin{array}{l}\text { Childcarel } \\
\text { education }\end{array}$ & $\begin{array}{c}\text { Education/ } \\
\text { Elderly }\end{array}$ & $\begin{array}{c}\text { Childcarel } \\
\text { elderly }\end{array}$ & $\begin{array}{l}\text { Childcarel } \\
\text { education }\end{array}$ & $\begin{array}{c}\text { Education/ } \\
\text { elderly }\end{array}$ \\
\hline Period & 1976-1997 & 1976-1997 & 1976-1997 & 1985-1997 & 1985-1997 & 1985-1997 \\
\hline $\begin{array}{l}\text { Women in council } \\
20-29 \%\end{array}$ & $\begin{array}{r}-0.018 \\
(0.83)\end{array}$ & $\begin{array}{l}-0.008 \\
(1.09)\end{array}$ & $\begin{array}{l}-0.013 \\
(0.67)\end{array}$ & & & \\
\hline $\begin{array}{l}\text { Women in council } \\
30-39 \%\end{array}$ & $\begin{array}{c}0.109 \\
(4.48)^{* * *}\end{array}$ & $\begin{array}{c}0.029 \\
(3.75)^{* * *}\end{array}$ & $\begin{array}{c}0.052 \\
(2.54)^{* *}\end{array}$ & & & \\
\hline $\begin{array}{l}\text { Women in council } \\
>40 \%\end{array}$ & $\begin{array}{c}0.115 \\
(1.98)^{* *}\end{array}$ & $\begin{array}{r}-0.008 \\
(0.61)\end{array}$ & $\begin{array}{c}0.118 \\
(2.51)^{* *}\end{array}$ & & & \\
\hline Women in majority & & & & $\begin{array}{c}0.651 \\
(3.00)^{* * *}\end{array}$ & $\begin{array}{l}0.076 \\
(1.31)\end{array}$ & $\begin{array}{c}0.564 \\
(2.71)^{* * *}\end{array}$ \\
\hline Control variables & yes & yes & Yes & yes & yes & yes \\
\hline Year FE & yes & yes & Yes & yes & yes & yes \\
\hline Mun. FE & yes & yes & Yes & yes & yes & yes \\
\hline Obs & 5436 & 5603 & 5425 & 2801 & 2739 & 2701 \\
\hline $\mathrm{R}^{2}$ & 0.84 & 0.84 & 0.88 & 0.85 & 0.83 & 0.87 \\
\hline
\end{tabular}

Standard errors are clustered on municipality level and t-statistics are presented in parentheses. $* * *$ indicate statistical significance at the $1 \%, * * 5 \%$ and $* 10 \%$ level. Control variables in the first three columns are the same as in Table 4 and in the last three columns the same as in Table 5 column 1, 3 and 5. 
Table 8. Dynamic specification .

\begin{tabular}{|c|c|c|c|c|c|c|}
\hline & $\begin{array}{c}\text { Childcarel } \\
\text { elderly }\end{array}$ & $\begin{array}{l}\text { Childcarel } \\
\text { education }\end{array}$ & $\begin{array}{l}\text { Education/ } \\
\text { elderly }\end{array}$ & $\begin{array}{c}\text { Childcarel } \\
\text { elderly }\end{array}$ & $\begin{array}{l}\text { Childcarel } \\
\text { education }\end{array}$ & $\begin{array}{c}\text { Education/ } \\
\text { elderly }\end{array}$ \\
\hline Period & 1976-1997 & 1976-1997 & 1976-1997 & 1985-1997 & $1985-1997$ & 1985-1997 \\
\hline$y(t-1)$ & $\begin{array}{c}0.780 \\
(13.17)^{* * *}\end{array}$ & $\begin{array}{c}0.758 \\
(23.51)^{* * *}\end{array}$ & $\begin{array}{c}0.633 \\
(13.67)^{* * *}\end{array}$ & $\begin{array}{c}0.573 \\
(7.12)^{* * *}\end{array}$ & $\begin{array}{c}0.606 \\
(14.61)^{* * *}\end{array}$ & $\begin{array}{c}0.571 \\
(8.51)^{* * *}\end{array}$ \\
\hline$y(t-2)$ & $\begin{array}{c}0.146 \\
(2.91)^{* * *}\end{array}$ & $\begin{array}{c}0.076 \\
(2.21)^{* *}\end{array}$ & $\begin{array}{c}0.187 \\
(5.70)^{* * *}\end{array}$ & $\begin{array}{c}0.292 \\
(6.18)^{* * *}\end{array}$ & $\begin{array}{c}0.123 \\
(4.07)^{* * *}\end{array}$ & $\begin{array}{c}0.201 \\
(4.27)^{* * *}\end{array}$ \\
\hline $\begin{array}{l}\text { Women in } \\
\text { council }\end{array}$ & $\begin{array}{c}0.346 \\
(2.86)^{* * *}\end{array}$ & $\begin{array}{l}0.023 \\
(0.51)\end{array}$ & $\begin{array}{c}0.450 \\
(3.13)^{* * *}\end{array}$ & & & \\
\hline $\begin{array}{l}\text { Women in } \\
\text { majority }\end{array}$ & & & & $\begin{array}{c}0.343 \\
(1.74)^{*}\end{array}$ & $\begin{array}{l}0.050 \\
(1.06)\end{array}$ & $\begin{array}{c}0.387 \\
(1.83)^{*}\end{array}$ \\
\hline Control variables & yes & yes & yes & yes & yes & yes \\
\hline Year FE & yes & yes & yes & yes & yes & yes \\
\hline Mun. FE & yes & yes & yes & yes & yes & yes \\
\hline \# of instruments & 242 & 249 & 242 & 223 & 224 & 223 \\
\hline $\mathrm{AR}(2) \mathrm{p}$-value & 0.464 & 0.929 & 0.186 & 0.165 & 0.106 & 0.092 \\
\hline $\begin{array}{l}\text { Hansen OID } \\
\text { p-value }\end{array}$ & 0.134 & 0.308 & 0.105 & 0.183 & 0.233 & 0.246 \\
\hline Obs & 4660 & 5387 & 4704 & 2659 & 2682 & 2573 \\
\hline
\end{tabular}

Standard errors are clustered on municipality level and t-statistics are presented in parentheses. $* * *$ indicate statistical significance at the $1 \%, * * 5 \%$ and $* 10 \%$ level. Estimations are made using the command xtabond 2 in STATA 9.2 developed by Roodman (see Roodman, 2006). All specifications use the two-step estimation with Windmeijer's finite-sample correction for the two-step covariance matrix. All variables are treated as predetermined, except for the year dummies which are treated as exogenous. $\operatorname{AR}(2)$ is the Arellano-Bond test for AR(2) in first differences and below is the p-value from the Hansen test of overid. restrictions presented. Control variables in the first three columns are the same as in Table 4 and in the last three columns the same as in Table 5 column 1, 3 and 5, except that dummies for left-wing and right-wing majorities are left out. The reason for this is to reduce the number of instruments. Including the dummies for majorities have no effect on the results. The instruments are also collapsed to further limit the number of instruments. 
Table 9. Interactions, women's representation and political majority.

\begin{tabular}{|c|c|c|c|c|c|c|c|}
\hline & $\begin{array}{c}\text { Childcarel } \\
\text { Elderly }\end{array}$ & $\begin{array}{l}\text { Childcarel } \\
\text { education }\end{array}$ & $\begin{array}{c}\text { Education/ } \\
\text { elderly }\end{array}$ & & $\begin{array}{c}\text { Childcarel } \\
\text { elderly }\end{array}$ & $\begin{array}{l}\text { Childcarel } \\
\text { education }\end{array}$ & $\begin{array}{c}\text { Education/ } \\
\text { elderly }\end{array}$ \\
\hline & $\begin{array}{l}1976- \\
1997\end{array}$ & $\begin{array}{l}1976- \\
1997\end{array}$ & $\begin{array}{l}1976- \\
1997\end{array}$ & & $\begin{array}{l}1985- \\
1997\end{array}$ & $\begin{array}{l}1985- \\
1997\end{array}$ & $\begin{array}{l}1985- \\
1997\end{array}$ \\
\hline $\begin{array}{l}\text { Women in } \\
\text { council }\end{array}$ & $\begin{array}{c}1.282 \\
(2.00)^{* *}\end{array}$ & $\begin{array}{l}0.143 \\
(0.72)\end{array}$ & $\begin{array}{c}0.953 \\
(2.22)^{* *}\end{array}$ & & & & \\
\hline $\begin{array}{l}\text { Women in } \\
\text { council*left- } \\
\text { wing majority }\end{array}$ & $\begin{array}{l}-0.055 \\
(0.12)\end{array}$ & $\begin{array}{l}0.017 \\
(0.09)\end{array}$ & $\begin{array}{l}-0.006 \\
(0.02)\end{array}$ & $\begin{array}{l}\text { Women } \\
\text { in left- } \\
\text { wing } \\
\text { majority }\end{array}$ & $\begin{array}{c}1.077 \\
(3.09)^{* * *}\end{array}$ & $\begin{array}{l}0.023 \\
(0.32)\end{array}$ & $\begin{array}{c}0.599 \\
(2.47)^{* *}\end{array}$ \\
\hline $\begin{array}{l}\text { Women in } \\
\text { council*right- } \\
\text { wing majority }\end{array}$ & $\begin{array}{l}-0.292 \\
(0.49)\end{array}$ & $\begin{array}{l}0.035 \\
(0.19)\end{array}$ & $\begin{array}{l}-0.475 \\
(1.10)\end{array}$ & $\begin{array}{l}\text { Women } \\
\text { in right- } \\
\text { wing } \\
\text { majority }\end{array}$ & $\begin{array}{c}1.397 \\
(4.84)^{* * *}\end{array}$ & $\begin{array}{c}0.155 \\
(2.15)^{* *}\end{array}$ & $\begin{array}{c}0.513 \\
(2.04)^{* *}\end{array}$ \\
\hline $\begin{array}{l}\text { Right-wing } \\
\text { majority }\end{array}$ & $\begin{array}{l}0.036 \\
(0.24)\end{array}$ & $\begin{array}{l}-0.025 \\
(0.50)\end{array}$ & $\begin{array}{l}0.125 \\
(1.05)\end{array}$ & $\begin{array}{l}\text { Right- } \\
\text { wing } \\
\text { majority }\end{array}$ & $\begin{array}{l}-0.111 \\
(1.10)\end{array}$ & $\begin{array}{l}-0.052 \\
(1.67)^{*}\end{array}$ & $\begin{array}{l}0.032 \\
(0.35)\end{array}$ \\
\hline $\begin{array}{l}\text { Left-wing } \\
\text { majority }\end{array}$ & 0.040 & $\begin{array}{l}0.001 \\
(0.02)\end{array}$ & $\begin{array}{l}-0.009 \\
(0.08)\end{array}$ & & & & \\
\hline $\begin{array}{l}\text { Control } \\
\text { variables }\end{array}$ & Yes & yes & yes & & yes & yes & yes \\
\hline Year FE & Yes & yes & yes & & yes & yes & yes \\
\hline Mun. FE & Yes & yes & yes & & yes & yes & yes \\
\hline Obs & 5953 & 6120 & 5955 & & 2801 & 2739 & 2701 \\
\hline $\mathrm{R}^{2}$ & 0.83 & 0.85 & 0.87 & & 0.66 & 0.83 & 0.87 \\
\hline
\end{tabular}

Standard errors are clustered on municipality level and t-statistics are presented in parentheses. $* * *$ indicate statistical significance at the $1 \%, * * 5 \%$ and $* 10 \%$ level. Control variables in the first three columns are the same as in Table 4 and in the last three columns the same as in Table 5 column 1, 3 and 5. 
Table 10. Interactions with political competition.

\begin{tabular}{|c|c|c|c|c|c|c|c|}
\hline & $\begin{array}{c}\text { Childcarel } \\
\text { Elderly }\end{array}$ & $\begin{array}{l}\text { Childcarel } \\
\text { education }\end{array}$ & $\begin{array}{c}\text { Education/ } \\
\text { elderly }\end{array}$ & & $\begin{array}{c}\text { Childcarel } \\
\text { elderly }\end{array}$ & $\begin{array}{l}\text { Childcarel } \\
\text { education }\end{array}$ & $\begin{array}{c}\text { Education/ } \\
\text { elderly }\end{array}$ \\
\hline & $\begin{array}{l}1976- \\
1997\end{array}$ & $\begin{array}{l}1976- \\
1997\end{array}$ & $\begin{array}{l}1976- \\
1997\end{array}$ & & $\begin{array}{l}1985- \\
1997\end{array}$ & $\begin{array}{l}1985- \\
1997\end{array}$ & $\begin{array}{l}1985- \\
1997\end{array}$ \\
\hline $\begin{array}{l}\text { Women in } \\
\text { council }\end{array}$ & $\begin{array}{c}1.137 \\
(1.77)^{*}\end{array}$ & $\begin{array}{r}-0.294 \\
(1.40)\end{array}$ & $\begin{array}{l}1.013 \\
(1.64)\end{array}$ & $\begin{array}{l}\text { Women } \\
\text { in maj. }\end{array}$ & $\begin{array}{c}2.172 \\
(2.35)^{* *}\end{array}$ & $\begin{array}{l}-0.149 \\
(0.55)\end{array}$ & $\begin{array}{c}1.926 \\
(2.32)^{* *}\end{array}$ \\
\hline $\begin{array}{l}\text { Women in } \\
\text { council } \times \\
\text { political } \\
\text { comp }\end{array}$ & $\begin{array}{l}-0.178 \\
(0.26)\end{array}$ & $\begin{array}{c}0.490 \\
(2.10)^{* *}\end{array}$ & $\begin{array}{l}-0.368 \\
(0.54)\end{array}$ & $\begin{array}{l}\text { Women } \\
\text { in maj } \times \\
\text { political } \\
\text { comp }\end{array}$ & $\begin{array}{l}-1.868 \\
(1.80)^{*}\end{array}$ & $\begin{array}{l}0.266 \\
(0.83)\end{array}$ & $\begin{array}{l}-1.671 \\
(1.69)^{*}\end{array}$ \\
\hline $\begin{array}{l}\text { Political } \\
\text { competition }\end{array}$ & $\begin{array}{l}0.122 \\
(0.54)\end{array}$ & $\begin{array}{c}-0.191 \\
(2.29)^{* *}\end{array}$ & $\begin{array}{l}0.104 \\
(0.46)\end{array}$ & & $\begin{array}{c}0.561 \\
(1.69)^{*}\end{array}$ & $\begin{array}{l}-0.162 \\
(1.30)\end{array}$ & $\begin{array}{c}0.611 \\
(1.80)^{*}\end{array}$ \\
\hline $\begin{array}{l}\text { Control } \\
\text { variables }\end{array}$ & Yes & yes & yes & & yes & yes & yes \\
\hline Year FE & Yes & yes & yes & & yes & yes & yes \\
\hline Mun. FE & Yes & yes & yes & & yes & yes & yes \\
\hline Obs & 5436 & 5603 & 5425 & & 2801 & 2739 & 2701 \\
\hline $\mathrm{R}^{2}$ & 0.84 & 0.84 & 0.88 & & 0.85 & 0.83 & 0.87 \\
\hline
\end{tabular}

Standard errors are clustered on municipality level and t-statistics are presented in parentheses. *** indicate statistical significance at the $1 \%, * * 5 \%$ and $* 10 \%$ level. Control variables in the first three columns are the same as in Table 4 and in the last three columns the same as in Table 5 column 1, 3 and 5. 